\title{
Enhanced logistic reactivity in the Forging Industry
}

\author{
ANIS SELAOUTI \\ Institute of Integrated Production Hannover, Hollerithallee 6, \\ Hannover, 30419, Germany \\ selaouti@iph-hannover.de \\ http://iph-hannover.de \\ JENS-MICHAEL POTTHAST \\ Institute of Integrated Production Hannover, Hollerithallee 6, \\ Hannover, 30419, Germany \\ potthast@iph-hannover.de \\ http://iph-hannover.de \\ ROUVEN NICKEL \\ Institute of Integrated Production Hannover, Hollerithallee 6, \\ Hannover, 30419, Germany \\ nickel@iph-hannover.de \\ http://iph-hannover.de
}

\section{Zusammenfassung}

Häufige Änderungen von Auftragsmengen oder -terminen durch die Kunden sowie ein unzuverlässiges Lieferverhalten der Zulieferer verursachen Turbulenzen, welche die innerbetriebliche Produktionsplanung und steuerung erschweren. Dies ist für Schmiedeunternehmen mit langen Rüstzeiten und großen Losgrößen besonders ausgeprägt. Eine frühzeitige Identifikation, Quantifizierung und Bewertung logistischer Risiken in der Lieferkette ermöglicht die Ableitung von Maßnahmen in der Produktionsplanung und -steuerung (PPS), um der Dynamik auf den Märkten zu begegnen. Im Rahmen des Forschungsprojekts SFB489 "Planung und Steuerung flexibler Lieferketten zur Herstellung präzisionsgeschmiedeter Bauteile" wurde eine Methode für die Integration eines logistischen Risikomanagement in die Produktionsplanung und -steuerung. In diesem Beitrag werden die Ergebnisse Forschungsprojekts in den Bereichen Risiko-Identifikation, -Bewertung und -Steuerung vorgestellt.

\begin{abstract}
Short term and frequent changes of delivery quantities and dates by customers as well as unreliable logistic behaviour of raw material suppliers cause logistic turbulences, which affect the accuracy of production planning and control (PPC). In order to assure more flexible reaction capability in combination with high level reliability of PPC, logistic risk management is essential, which enables an early identification, assessment and control of logistic risks in the supply chain. Within the research project SFB 489 C4 - "design and control of flexible supply chains for the production of precision forged components" a comprehensive approach was developed for the implementation of logistic risk management in PPC in flexible supply chains. This paper describes the developed methods for risk identification, risk assessment and risk control as well.
\end{abstract}

Keywords Production Management; Production Planning and Control; Risk Management; Material Flow Simulation.

\section{Introduction}

By reason of the intense competition in forging industry, forging companies have to forecast logistic risks on supply chain level as well as on shop floor level in order to avoid them and to ensure consequently competitive advantages (Wiendahl et al., 2007). In this context, logistic risks endanger the logistic objectives "low work in process", "high resource utilization", "short throughput time" and "high degree of schedule reliability" (e. g. fluctuating customer demands, non availability of resources in production or high delivery date deviation caused by raw material supplier) (Lambert and Douglas, 2008; Simchi-Levi and Kaminsky, 2007). With the intention of 
coping with logistic risks, methods ought to be conceptualized to implement logistic risk management in the PPC.

The quantification of logistic risks is a major factor of success for logistic risk management (Zolkos, 2003). Nevertheless, there are a very few effective and practical approaches for assessment of logistic risks (Jüttner; Ziegenbein, 2006). The lack of such approaches was affirmed within a literature review on the field supply chain risk management performed by Buscher, Wels and Winter (Buscher; Wels and Winter, 2008). Within the literature review about 346 publications were analysed. Thereby, $87 \%$ of publications reviewed are presenting approaches for qualitative assessment of logistic risks. On the contrary, less than $2 \%$ of reviewed publications are handling with approaches which quantify risks in the supply chain. Hence, there is particular need for research on risk assessment in logistics (Buscher; Wels and Winter, 2008).

Within the research project SFB 489 C4 - "design and control of flexible supply chains for the production of precision forged components" a comprehensive approach was developed for the implementation of operative logistic risk management in the PPC in flexible supply chains (Nickel, 2008). The logistic risk management was conceptualized as a PPC controlling task. The conventional PPC controlling assists the production scheduler by providing transparent and coherent information about the present manufacturing state to guarantee a targetoriented configuration of processes, resources and manufacturing orders (Luczak et al., 1998). Fig. 1 shows the expansion of the PPC controlling by logistic risk management in order to forecast the future manufacturing state and to handle logistic risks (Selaouti et al., 2008).

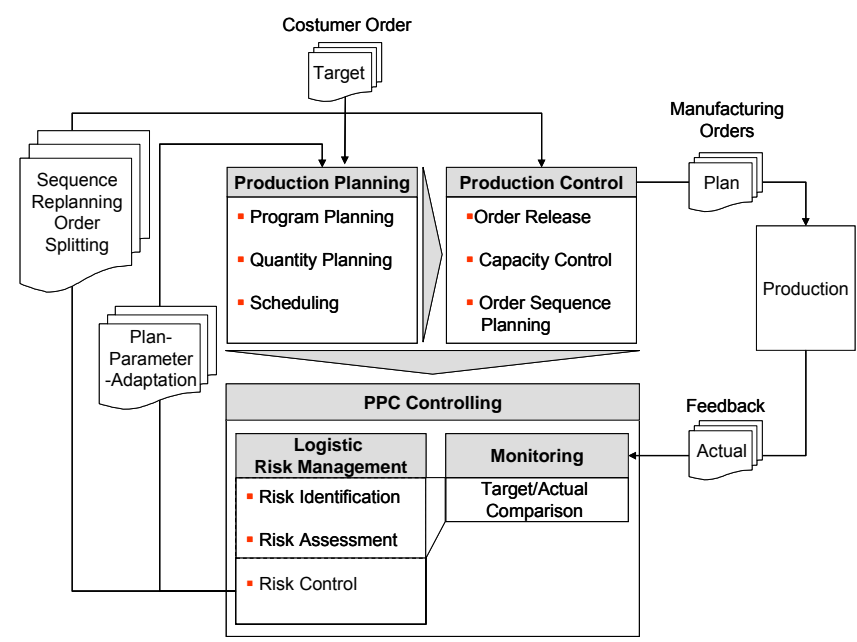

Fig. 1. Extension of the PPC controlling through logistic risk management (Selaouti et al., 2008)

The logistic risk management needs input information from the supply chain monitoring to assist the production scheduler with counter measures. These counter measures are subdivided into long term measures and short term measures. Long term measures are implemented by adapting plan-parameter (e. g. adaptation of order throughput time or order quantity). Short term measures present an integral part of the production control. This paper focuses on the short term measure "order sequence replanning". Consequently the impact of logistic risks can be avoided or minimized.

This paper presents an overview of results within the research project SFB 489 C4.

\section{Logistic Risk Management in the Supply Chain}

The superior goal of logistic risk management is to handle a manageable number of potential risks at the company level as well as at the supply chain level (Wiendahl et al., 2007). Therefore, the risks that are relevant to the subject supply chain have to be identified first. Then they need to be ranked according to occurrence and impact. In order to do this, methods have been developed that are based on statistical fundamentals. Finally, the potential logistic risks have to be controlled by avoiding them or by minimizing their impact through counter measures.

\subsection{Logistic Risk Indicators}

The risk identification is an essential part of risk management (Romeike, 2002). In this paper, the subject of research is a forging company acting as a first tier supplier of precision forged components to several industries. A global identification of logistic risks in the process chain for precision forging is decisive for the successive 
phases risk assessment and risk control. In order to do this, a system boundary was defined for the subject process chain. The system boundary encompasses the processes source, make and deliver according to SCOR (Supply-Chain Council, 2009). The source and deliver processes of the company represent the interface to the other elements (suppliers and customers) in the supply chain. On the one hand, the risk identification proceeded here based on a peer literature research. Researches from Wannenwetsch (Wannenwetsch, 2005), Wildemann (Wildemann, 2005), Schulte (Schulte, 2001) and the dissertations of Reinsch (Reinsch, 2003), Kanitz (Kanitz, 2002) and Ruta (Ruta, 1999) were fundamental. On the other hand, the risk identification resulted from interviews with experts on the field production logistics in forging companies based on Ishikawa Diagrams. Finally, logistic risk indicators were defined in each process, in order to assess logistic risks (Nickel, 2008). In the following, logistic risk indicators will be presented.

\subsubsection{Logistic Risk Indicators in the Source Process}

In the source process, logistic risks are mainly caused by the raw material supplier (e.g. through inaccurate delivery date). In the research project SFB $489 \mathrm{C} 4$, the following logistic risks are the most relevant for the considered supply chain for precision forging (Ruta, 1999):

- deviations of delivery date

- deviations delivery quantity

- variations in quality of the supplied material

The quantitative evaluation of the cited logistic risks is provided by logistic risk indicators.

The reaction on deviation of delivery date becomes more acute by time-consuming deliveries (Wiendahl, 1995). Therefore, the evaluation of logistic risk deviation of delivery date is based on the risk indicator mean weighted deviation of delivery date (DDmw) in scheduled calendar days (SCD). DDmw is calculated as follows:

$$
\mathrm{DD}_{\mathrm{mw}}=\frac{\sum_{\mathrm{i}=1}^{\mathrm{n}} \mathrm{DD}_{\mathrm{i}} \cdot \mathrm{LT}_{\mathrm{i}}}{\sum_{\mathrm{i}=1}^{\mathrm{n}} \mathrm{LT} \mathrm{T}_{\mathrm{i}}}
$$

with:

$\mathrm{DD}_{\mathrm{mw}}$ : Mean weighted deviation of delivery date [SCD]

$\mathrm{DD}_{\mathrm{i}}$ : Mean deviation date of delivery [SCD]

LT: $\quad$ Lead time [SCD]

i: $\quad$ Delivery [-]

The logistic risk deviation of delivery quantity is evaluated based on the risk indicator mean deviation of delivery quantity (DQm). This risk indicator is calculated according to equation 2.

$$
D Q_{m}=\frac{\sum_{i=1}^{n} D Q_{i}}{n}
$$

with:

$\mathrm{DQ}_{\mathrm{m}}: \quad$ Mean deviation of delivery quantity [U]

$\mathrm{DQ}_{\mathrm{i}}$ : $\quad$ Quantity deviation of a delivery [U]

n: $\quad$ Number of deliveries in a period [-]

i: $\quad$ Delivery [-]

Furthermore the logistic risk variations in quality of the supplied material are described through the risk indicator mean quality rate Qm (equation 3).

$$
Q_{m}=\frac{\sum_{i=1}^{n} \frac{Q_{\text {good }, i}}{Q_{i}}}{n}
$$

with:

$\mathrm{Q}_{\mathrm{m}}: \quad$ Mean quality rate [-]

$\mathrm{Q}_{\mathrm{i}}$ : $\quad$ Quantity of a delivery [U]

$\mathrm{Q}_{\text {good, i: }}$ Quantity of quality conform goods in a delivery [U]

$\mathrm{n}$ : $\quad$ Number of deliveries in a period [-]

i: $\quad$ Delivery [-] 


\subsubsection{Logistic Risk Indicators in the Make Process}

The quantification of the impact of logistic risk on the logistic objectives is fundamental to co-ordinate the processes source, make and deliver. Exemplary, a volatile throughput time in the make process influences the accuracy of inventory management in the source and deliver processes. Consequently, risk indicators have to defined in the make process, in order to quantify influences of logistic risks on logistic objectives.

In the make process, logistic risks were identified on process and resource level. For this intention, logistic risks are defined at process level by modelling the operations in each process based on throughput elements. Fig. 2 shows exemplary the modelling of the operation precision forging. The throughput time consists of the sub elements "inter-operation time", "set-up time" and "processing time" (Wiendahl, 1995). These elements represent the starting point to derive the logistic risks at process level. The dependencies between logistic objectives and logistic risks can be established based on the funnel model. The funnel model allows a mathematical formulation of the independencies between the logistic performance measures output rate, work in process and throughput time, which measure the logistic objectives (Nyhuis and Wiendahl, 2002).

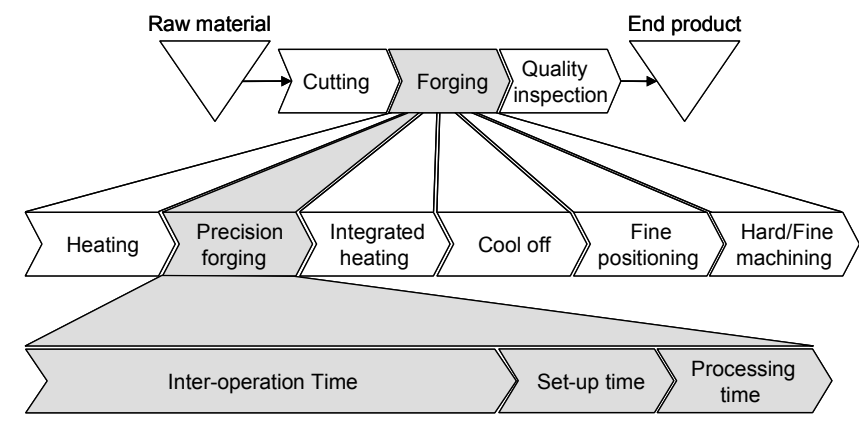

Fig. 2. Logistic Modelling of the Operation Precision Forging

At resource level logistic risks can be identified, which are caused by quality losses as well as machine and workforce availability losses. These losses affect the maximal possible output rate in a working system (Nyhuis and Wiendahl, 2002).

Table 1 contains the logistic risks with their associated risk indicators for the precision forging operation. The risks are the result of a survey in the forging industry and are separated in risks at process level and at resource level. The risk indicators are deduced based on the cause (influencing factor) of each logistic risk. For example, the set-up time while processing a lot increases, when the press-tool endurance is shorter than the lot processing time. In this case, the risk indicator "rapport between lot processing time and the tool endurance" must be reduced to avoid an increase of set-up time. 
Table 1: Logistic risks in the precision forging operation in the reference process chain (Wiendahl et al., 2007)

\begin{tabular}{|c|c|c|c|c|}
\hline & \multicolumn{2}{|c|}{ Logistic Risk } & Cause & Risk indicator \\
\hline \multirow{9}{*}{$\begin{array}{l}\text { Process } \\
\text { level }\end{array}$} & \multirow{3}{*}{\multicolumn{2}{|c|}{$\begin{array}{l}\text { High inter-operation } \\
\text { time }\end{array}$}} & $\begin{array}{l}\text { High buffer } \\
\text { inventory }\end{array}$ & Mean buffer inventory \\
\hline & & & High date & Mean lateness \\
\hline & & & press input & Lateness variance \\
\hline & \multirow{4}{*}{\multicolumn{2}{|c|}{ High set-up time }} & $\begin{array}{c}\text { Set-up } \\
\text { procedure }\end{array}$ & Mean set-up time \\
\hline & & & Tool life time & Mean tool life time \\
\hline & & & Lot size & $\begin{array}{l}\text { Rapport between lot } \\
\text { processing time and tool } \\
\text { life time }\end{array}$ \\
\hline & & & & Set up frequency \\
\hline & \multirow{2}{*}{\multicolumn{2}{|c|}{ High processing time }} & Handling & Handling time \\
\hline & & & Forging tact & Tact duration \\
\hline \multirow{5}{*}{$\begin{array}{l}\text { Resource } \\
\text { level }\end{array}$} & \multirow{4}{*}{$\begin{array}{l}\text { Low } \\
\text { working } \\
\text { system } \\
\text { capacity }\end{array}$} & \multirow[b]{2}{*}{$\begin{array}{l}\text { Low } \\
\text { equipment } \\
\text { capacity }\end{array}$} & $\begin{array}{c}\text { Machine } \\
\text { breakdown }\end{array}$ & $\begin{array}{c}\text { Technical equipment } \\
\text { availability rate }\end{array}$ \\
\hline & & & $\begin{array}{l}\text { Machine } \\
\text { maintenance } \\
\text { Legal } \\
\text { restraint }\end{array}$ & $\begin{array}{l}\text { Organizational } \\
\text { equipment availability } \\
\text { rate }\end{array}$ \\
\hline & & \multirow{2}{*}{$\begin{array}{l}\text { Low } \\
\text { workforce } \\
\text { capacity }\end{array}$} & $\begin{array}{l}\text { Workforce } \\
\text { availability }\end{array}$ & $\begin{array}{c}\text { Workforce availability } \\
\text { rate }\end{array}$ \\
\hline & & & $\begin{array}{l}\text { Usable } \\
\text { workforce } \\
\text { capacity }\end{array}$ & Performance rate \\
\hline & \multicolumn{2}{|c|}{ High quality losses } & $\begin{array}{l}\text { Scrap and } \\
\text { rework }\end{array}$ & Quality rate \\
\hline
\end{tabular}

Risk indicators in the make process are also mathematically formulated. Exemplary, the risk indicator "rapport between lot processing time and tool life time" in a period of examination indicates, if the lot size of produced orders is suitable for the throughput element set-up time. This risk indicator is calculated as follows:

$$
\mathrm{R}_{\mathrm{LT}}=\frac{\sum_{\mathrm{i}=1}^{\mathrm{n}} \mathrm{TP}_{\mathrm{i}}}{\sum_{\mathrm{i}=1}^{\mathrm{n}} \mathrm{TLT}_{\mathrm{i}}}
$$

with:

$\mathrm{R}_{\mathrm{LT}}$ : $\quad$ Rapport between lot processing time and tool life time [-]

$\mathrm{TP}_{\mathrm{i}}$ : $\quad$ Lot Processing Time of an order $\mathrm{i}$ in the period of examination [hrs]

TLT $_{\mathrm{i}}$ : Tool life time of the precision forging tool $\mathrm{i}$ [hrs]

$\mathrm{n}$ : $\quad$ Number of production orders in the period of examination [-]

\subsubsection{Logistic Risk Indicators in the Deliver Process}

In the delivery process, logistic risks are mainly caused by the customer behaviour through cancellation or changing delivery orders. In order to measure the fluctuation of customer demand JACOBSEN developed indicators. These are covering the demand volatility and the forecast accuracy (Jacobsen, 2006). The indicators are calculated according to the warehouse throughput diagram using areas for the mean and real output (Jacobsen, 2006). On fig. 3 a warehouse throughput diagram is depicted for an exemplary product. Thereby an idealised output is discrete (e.g. a delivery per day) so the cumulated output is shown in a step curve with time constant jumps and not as a straight line. On the lefts side of fig. 3 the curve of the cumulated output is compared with the curve of the idealised output, so the area of cumulative deviation is calculated. On the right side of fig. 3 the area of cumulated output in the considered period is depicted 


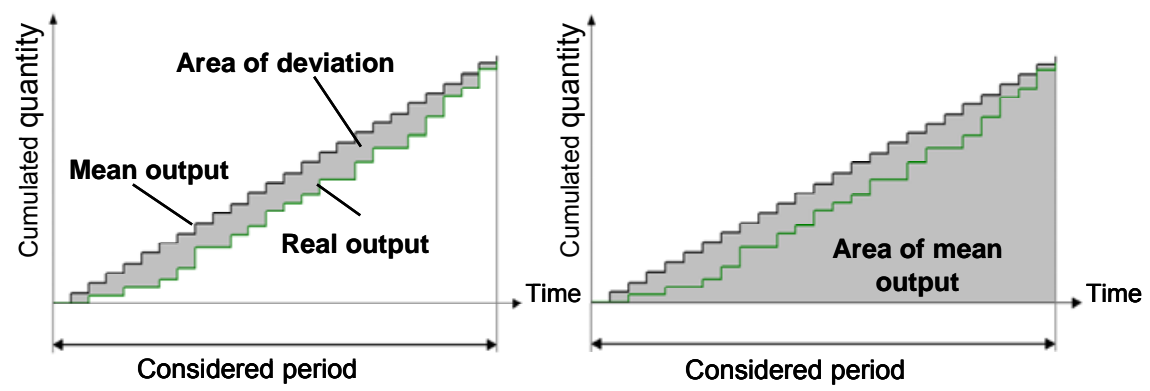

Fig. 3. Warehouse throughput diagram for an exemplary product demand (Jacobsen, 2006)

The demand volatility is calculated according to the following equation:

$$
D V=\frac{A_{d}}{A_{\text {mout }}}
$$

with:

DV: Demand volatility [-]

$\mathrm{A}_{\mathrm{d}}$ : Area of cumulative deviation between release and the real output in the considered period [U.SCD]

$\mathrm{A}_{\text {out }}$ : Area of mean output in the considered period [U.SCD]

Furthermore Jacobsen describes the customer behaviour based on the indicator forecast accuracy (Jacobsen, 2006). This indicator valuates the reliability of the predictions related to the release of delivery and it is calculated as follows:

$$
F A=\frac{A_{d}}{A_{\text {out }}}
$$

with:

FA: Forecast accuracy in the considered period [-]

$\mathrm{A}_{\mathrm{d}}$ : Area of cumulative deviation between release and the real output in the considered period [U.SCD]

$\mathrm{A}_{\text {out }}: \quad$ Area of output in the considered period [U.SCD] 


\subsection{Risk assessment}

The first step in the risk assessment is to forecast values of risk indicators for the next planning period. For this purpose, risk indicators of previous periods have to be analyzed on a logistic control chart, so that their trend can be determined. Fig. 4 shows the method to define the logistic control chart, which is based on the quality control chart, as it is employed in quality management for a statistical process control (Giesbrecht et al., 2004; Reinsch, 2003).

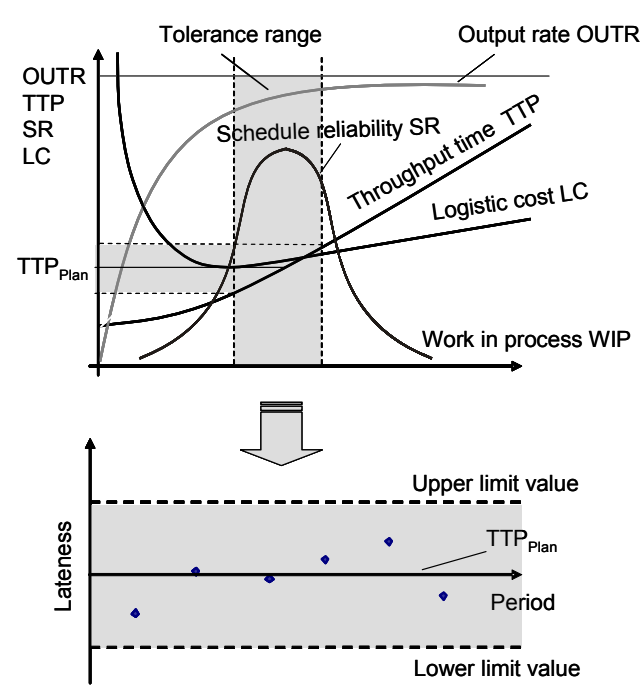

Fig. 4. Defining tolerance ranges on logistic control charts (Nickel, 2008)

In logistic risk management, logistic control charts are used to analyze the trend of logistic risk indicators. The tolerance range on the chart is bounded by a lower and an upper limit value (ULV and LLV). These limits are derived from the logistic-costs-effect-model from KERNER (Kerner, 2002). This model was developed to analyze the logistic cost changes in function of the deviation of logistic objectives in a process chain based on activitybased costing (Ouali and Reinsch, 2004). This approach enables an appropriate assigning of logistic costs, which comprise manufacturing costs as well as overhead costs to the elements of a process chain (Nyhuis and Wiendahl, 2002). In order to associate logistic costs with the logistic performance measures output rate, work in process, throughput time and schedule reliability, the logistic-cost-curve and the logistic-operating curves are depicted in a common diagram (see the top of fig. 4)

Corresponding to the logistic costs range, which is defined by the production scheduler, the tolerance ranges for the logistic performance measures can be derived from the logistic operating curves, developed by Nyhuis (Nyhuis and Wiendahl, 2002) (see bottom of fig. 4).

In order to identify the trend on the logistic control chart, miscellaneous statistical methods were tested regarding to the following requirements:

- Compensation for volatile changes

- Upper loading of current values of risk indicators in order to consider already achieved logistic measures.

The method of second order exponential smoothing complies best with the above-mentioned requirements (Kanitz, 2002). Furthermore, previous research demonstrated the effective use of this method in material requirements, program and sales planning in ERP systems (Reinsch, 2003; Kanitz, 2002). Therefore, forecast values for risk indicators can be well calculated through the method of second order exponential smoothing (Selaouti et al., 2008).

The calculated forecast value of a risk indicator is just an expected value, which does not definitively occur. Furthermore, during the next period the risk indicator can reach a value within a range of the forecasted value. Hence, the occurrence of risks has to be evaluated by the probability of occurrence, which is in accordance with the probability that the risk indicator is going below the lower limit value or crossing the upper limit value on the logistic control chart.

In order to determine this probability of occurrence it is essential to examine the distribution of the risk indicator values during previous periods. For this purpose, the Kolmogorov-Smirnov test (often called the K-S test) is used to determine whether the distribution of the subject risk indicator is according to the normal distribution, distribution, exponential distribution or distribution of Weibull. The first step before executing a K-S test is to hypothesize a distribution form for the subject risk indicator. This distribution is called the null hypothesis 
(Sachs, 1997). The next step consists in the K-S test which compares the empirical distribution function (deduced from risk indicator values of previous periods) with the cumulative distribution function specified by the null hypothesis. The procedure has to be repeated until a suitable distribution is established.

Here the procedure to determine the probability of occurrence is explained through the normally distributed risk indicator lateness $(\mathrm{Yu}, 2001)$. In the normal distribution curve, the expected value accords with the forecast value $\left(\mathrm{L}_{\mathrm{T}+1}^{*}\right)$. As pictured in fig. 5, the probability of occurrence corresponds to the area P. In this case, the logistic risk "high inter-operation time" occurs, if the forecasted lateness crosses the upper limit value on the logistic control chart.

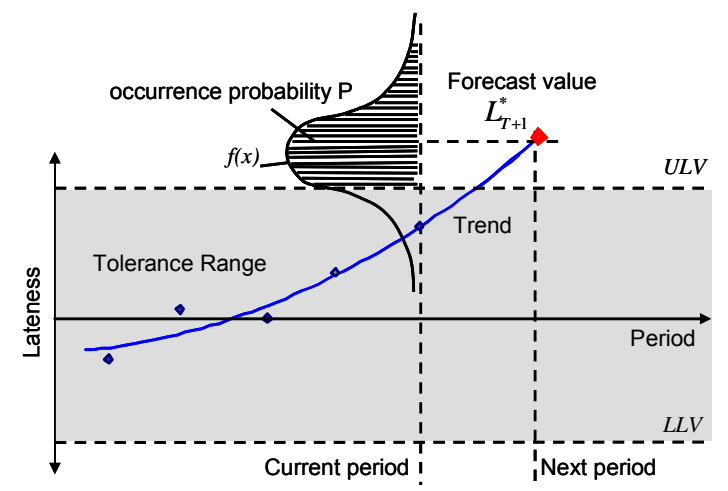

Fig. 5. Calculating the occurrence probability of lateness (Wiendahl et al., 2008)

Legend:

ULV: Upper limit value,

LLV: Lower limit value

$\mathrm{f}(\mathrm{x})$ : Distribution function

Accordingly, the occurrence probability $\mathrm{P}$ has to be determined as follows:

with:

$$
P_{L}=\int_{U L V_{L}}^{+\infty} \frac{1}{\sqrt{2 \pi \sigma_{L}{ }^{2}}} \cdot e^{-\frac{\left(L-L_{T+1}^{*}\right)^{2}}{2 \sigma_{L}^{2}}} d x
$$

$\mathrm{P}_{\mathrm{L}}$ : $\quad$ Occurrence probability of lateness [-]

$\sigma_{L^{*}}: \quad$ Standard deviation according to the distribution of lateness values in previous periods [SCD]

$\mathrm{L}^{*}{ }_{\mathrm{T}+1}$ : $\quad$ Forecasted lateness value [SCD]

$\mathrm{ULV}_{\mathrm{L}}$ : $\quad$ Upper limit value of lateness [SCD]

The second step in the risk assessment is to consider the relative economic impact of logistic risks in addition to their probability of occurrence. The value can be derived from the logistic-costs-effect-model from Kerner (Nyhuis and Wiendahl, 2002). Fig. 6 shows exemplary the economical impact of lateness. According to the current manufacturing state, the schedule reliability and the logistic-costs curves are depicted. In order to establish the economical impact when the lateness at a working system is above the upper limit value on the logistic control chart, the schedule reliability value $\left(\mathrm{SR}_{\mathrm{T}+1}\right)$ is calculated according forcasted of lateness $\left(\mathrm{L}^{*}{ }_{\mathrm{T}+1}\right)$. Based on the calculated schedule reliability value $\left(\mathrm{SR}_{\mathrm{T}+1}\right)$ the logistic costs $\left(\mathrm{LC}_{\mathrm{T}+1}\right)$ can be found on the logistic costs curve. 


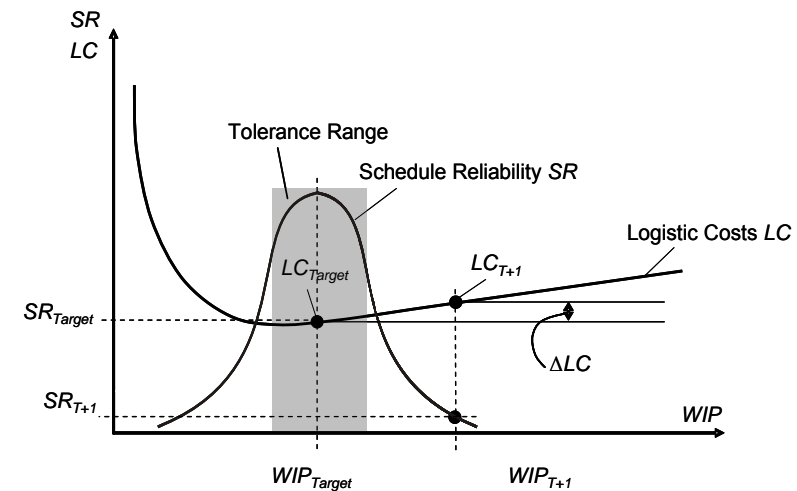

Fig. 6. Determining the relative economic impact of lateness

$\begin{array}{ll}\text { Legend: } & \\ \mathrm{SR}_{\text {Target }}: & \text { Target schedule reliability [-] } \\ \mathrm{SR}_{\mathrm{T}+1}: & \text { Expected Schedule reliability according to the forecasted value of lateness [-] } \\ \mathrm{WIP}_{\text {Target }}: & \text { Target work in process [hrs] } \\ \mathrm{WIP}_{\mathrm{T}+1}: & \text { Expected work in process according to the forecasted value of lateness [hrs] } \\ \mathrm{LC}_{\mathrm{Target}}: & \text { Target logistic costs }[€] \\ \mathrm{LC}_{\mathrm{T}+1}: & \text { Expected logistic costs according to the forecasted value of lateness }[€] \\ \Delta \mathrm{LC}: & \text { Loss according to the forecasted value of lateness }[€]\end{array}$

The relative economic impact of lateness can then be calculated as follows:

$$
W_{L}=\frac{L C_{T+1}-L C_{T \text { arget }}}{L C_{T \text { arg et }}}
$$

with:

$\mathrm{W}_{\mathrm{L}}$ : $\quad$ Relative economic impact of lateness [-]

$\mathrm{LC}_{\text {Target }}: \quad$ Target logistic costs $[€]$

$\mathrm{LC}_{\mathrm{T}+1}$ : Expected logistic costs according to the forecasted value of lateness $[€]$

After determining the assessment criteria - probability of occurrence and relative economic impact - a manageable number of logistic risks can be established. For this purpose, the logistic risks have to be classified regarding to assessment criteria into three classes A, B and C. Thereby, A-Risks are characterized by a high probability of occurrence and/or high relative economic impact. Therefore, they have to be addressed first. BRisks are less acute and can be tolerated for some time, i.e. they are to be taken care of after the A-Risks. Furthermore, C-Risks can be neglected because they are no real threat for the logistic objectives. Afterwards, the logistic risks are ranked according to the risk value, which is defined as the product of probability of occurrence and relative economic impact.

$$
R V=P \cdot W
$$

with:

RV: $\quad$ Risk value [-]

P: $\quad$ Occurrence probability [-]

W: Relative economic impact [-]

The table below shows an extract from a risk evaluation matrix. The extract contains 4 evaluated logistic risks for the logistic objective "low through put time". In this test evaluation the risk classes are defined through the value limits of probability of occurrence and relative economic impact: class A higher than 0.4 , class B between 0.2 and 0.4 and class $\mathrm{C}$ lower than 0.2 .

Table 2: Extract from a risk evaluation matrix (Wiendahl, 2007)

\begin{tabular}{|c|l|c|c|c|c|}
\hline Nr. & \multicolumn{1}{|c|}{ Risk indicator } & $\begin{array}{c}\text { Occurrence } \\
\text { probability P }\end{array}$ & $\begin{array}{c}\text { Economical } \\
\text { impact W }\end{array}$ & $\begin{array}{c}\text { Risk } \\
\text { value RV }\end{array}$ & $\begin{array}{c}\text { Rank } \\
\text { Class }\end{array}$ \\
\hline & Throughput time & & & & \\
\hline 1 & $\begin{array}{l}\text { Mean relative throughput time } \\
\text { deviation }\end{array}$ & 0.95 & 0.49 & 0.47 & $\mathrm{~A}-1$ \\
\hline 2 & $\begin{array}{l}\text { Mean variance of relative } \\
\text { throughput time deviation }\end{array}$ & 0.36 & 0.12 & 0.04 & $\mathrm{C}-1$ \\
\hline 3 & Mean flow rate & 0.80 & 0.42 & 0.34 & $\mathrm{~B}-1$ \\
\hline 4 & Mean set-up time & 0.09 & 0.17 & 0.02 & $\mathrm{C}-2$ \\
\hline
\end{tabular}




\subsection{Risk control}

The aim of risk control is to initiate adequate counter measures for minimizing the probability of occurrence or the impact of logistic risks. In the long term, the production scheduler uses material flow simulation, in order to adapt plan parameter. In the short term he tries to reduce the impact of logistic risks by changing the sequence of production orders.

\subsubsection{Simulation-based plan-parameter adaptation for long term risk control}

Generally, the production scheduler has to manage many logistic risks at the same time. Conventionally, he tries to adapt the PPC plan-parameter (e. g. planned throughput time, maximum output rate and minimum work in process) according to the assigned counter measures based on his experience as well as appraised values, so the quality of the risk relies mainly on his experience. However, the plan-parameter adaptation in this project proceeds systematically based on material flow simulation in order to guarantee a high quality of risk control independent from the production scheduler know-how. The guideline 3633 of the VDI (Association of German Engineers) defines the material flow simulation as the mapping of "technical systems" with all its dynamic processes in an experimentation model. The term technical system represents logistic processes, material flow and production systems (VDI, 1997).

Fig. 7 shows the procedure for the simulation-based plan-parameter adaptation. The adaptation starts with an initial plan-parameter set (e. g. release dates of production orders), which is defined from the scheduler. Based on the initial plan-parameter set a production program is created, which has to be simulated through the simulation model. Afterwards, the output information of simulation model (e. g. completion dates of production orders) are evaluated and logistic risks are assessed. In order to minimize the probability of occurrence and impact of logistic risks a new plan-parameter set is generated by genetic algorithms. Thereby, the plan-parameter adaptation proceeds in a closed loop until parameter set is established, which ensure achieving logistic objectives.

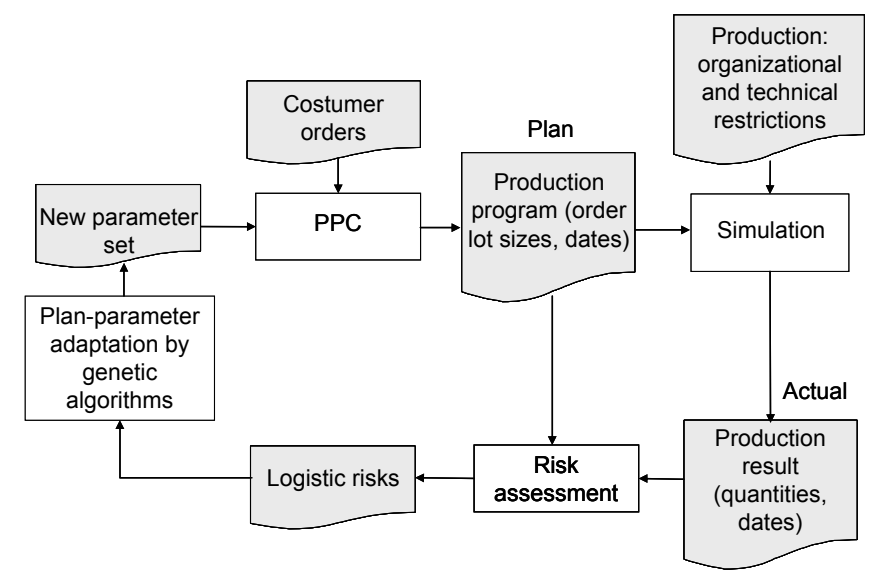

Fig. 7. Simulation-Based Plan-Parameter Adaptation for Long Term Risk Control (Selaouti et al., 2008)

\section{Subject of Simulation}

The subject of simulation is a process chain for precision forging. Thereby, the modelling of different operations in the process chain is based on throughput elements.

The main task of the simulation model is to verify whether the manufacturing orders can be processed according to the plan after the adaptation of plan-parameter. By this means, the plan-parameter adaptation can be validated. The input data for this simulation model are the planned manufacturing orders and the output data are the produced quantities as well as beginning and completion dates. After simulation the output data are used by the genetic algorithms to adapt plan parameter. The use of genetic algorithms will be explained in the following paragraph.

\section{Genetic Algorithms for Plan-Parameter Adaptation}

Genetic algorithms are an established particular class of evolutionary algorithms (also known as evolutionary computation) that use techniques inspired by evolutionary biology such as inheritance, mutation, selection, and crossover (also called recombination) (Goldberg, 2002). They are suitable for time-consuming optimization problems (Fang and Sudjianto, 2006). Hence, genetic algorithms seem to be well appropriated for the planparameter adaptation because of the high number of degrees of freedom in production. 
Fig. 8 shows the procedure of the optimization through genetic algorithms. Starting with randomly chosen initial release dates of production orders (start population) the deviation from schedule is determined by simulating the production program (cp. fig.8).

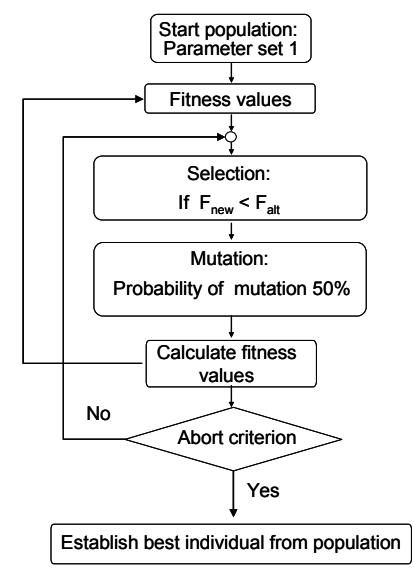

Fig. 8. Procedure of Genetic Algorithms

In order to evaluate the schedule reliability an evaluation function (equation 10) was defined, which is also used as fitness function (F) for the genetic algorithms.

$$
F=\sqrt{\frac{\sum_{i=1}^{n}\left(L_{i}\right)^{2}}{n}}
$$

with:

F: Fitness function [SCD]

$\mathrm{L}_{\mathrm{i}}$ : Lateness [SCD]

$\mathrm{n}$ : Number of production orders [-]

i: $\quad$ Variable [-]

\subsubsection{Order Sequence Replanning for Short Term Risk Control}

In many cases the production in forging companies gets disturbed through rush orders, which arise out of highly fluctuating customer demands (logistic risk). Rush orders are highly prioritized and cause sequence permutations in the existing order waiting queue. Such permutations extend the throughput time of the remaining orders and consequently endanger the mean schedule reliability (Nyhuis and Wiendahl, 2002). Hence, a method for order sequence replanning will be presented as part of short term risk control. Thereby the main goal of this method is to exchange the position of a rush order with an order in an existing waiting queue in order to ensure the adherence to scheduled completion of all production orders.

Fig. 9 shows an exemplary initial situation in a forging plant. At a reference day $\left(\mathrm{T}_{\text {ref }}\right)$ a new production order $\left(\operatorname{Order}_{R}\right)$ is released. Depending on the current load at the forging aggregate the new production order can not be completed at his scheduled completion date $\left(\mathrm{T}_{\text {PlanEnd, } \mathrm{R}}\right)$. Thereby, the current load at the forging aggregate accords to the work content of waiting production orders in the initial sequence. A delayed completion of production $\operatorname{Order}_{\mathrm{R}}$ may increase the probability of the logistic risk "low schedule reliability". Consequently the new production order becomes a rush order $\left(\operatorname{Order}_{R}\right)$. 


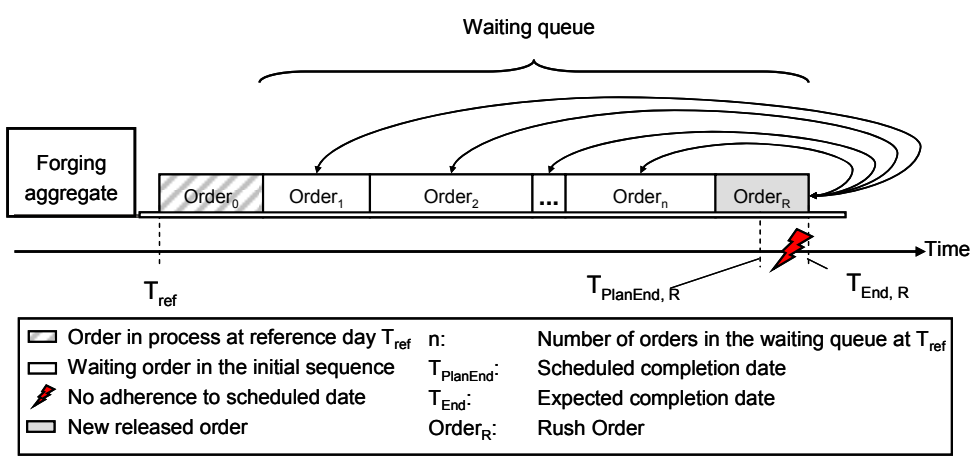

Fig. 9. Initial Situation for Order Sequence Replanning

The scheduled completion date of the rush order can not be met by the reason that the buffer time $\left(\mathrm{BT}_{\mathrm{R}}\right)$ is negative (equation 10). Thereby, the buffer time accords to the duration between the reference day $\left(\mathrm{T}_{\text {ref }}\right)$ and the scheduled completion date of a production order $\left(\mathrm{T}_{\mathrm{PlanEnd}}\right)$ excepting the time for its processing and the waiting time due to its position in the waiting queue. A negative value of buffer time indicates the capacity of the forging aggregate is not sufficient to complete the rush order at its scheduled completion date.

$$
B T_{R}=T_{\text {PlanEnd,R }}-T_{\text {ref }}-\sum_{i=1}^{n+1} T E X_{i}-T E X_{0, R e s t}
$$

with:

$\mathrm{BT}_{\mathrm{R}}$ : $\quad$ Buffer time of the rush order [hrs]

$\mathrm{T}_{\text {PlanEnd,R: }}$ Scheduled completion date of the rush order [SCD]

$\mathrm{T}_{\text {ref }}$ : $\quad$ Release date of the rush order [SCD]

TEX: $\quad$ Order execution time (processing time and set-up time) [hrs]

$\mathrm{TEX}_{0, \text { Rest }}$ : Remaining execution time of the order in processing at $\mathrm{T}_{\text {ref }}[\mathrm{hrs}]$

i: $\quad$ Variable [-]

$\mathrm{n}$ Number of waiting orders at $\mathrm{T}_{\text {ref }}[-]$

At the beginning, the rush order $\left(\operatorname{Order}_{R}\right)$ gets the last position in the waiting queue (fig. 9). Afterwards, it can change its position with an order whereas the other orders have to retain their initial positions. Thereby, this sequence permutation has to conform to two conditions. On the one hand, the permutation must ensure the adherence to scheduled completion dates of the rush order and the permuted order. On the other hand, the permutation has not to endanger the general schedule reliability in the production. The method encompasses three selection levels (see fig. 10).

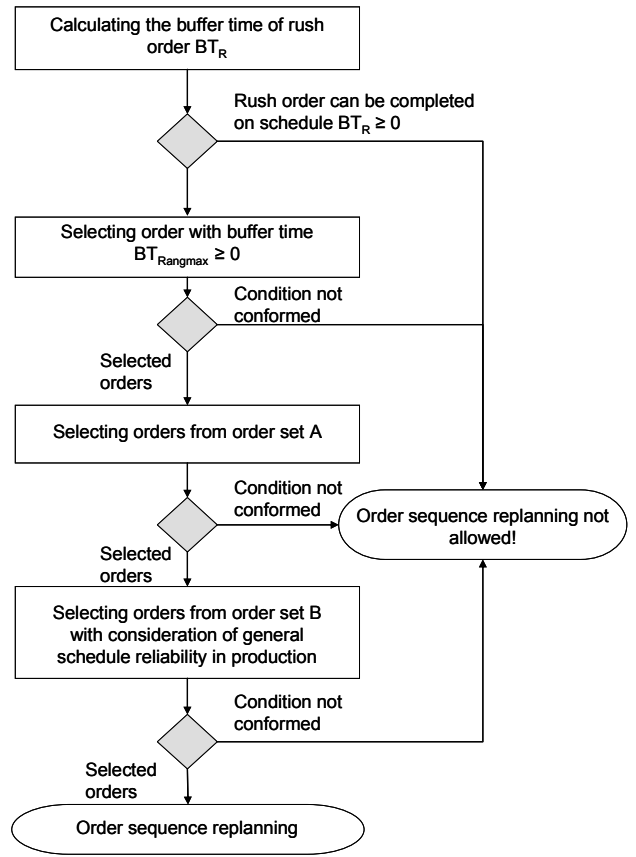

Fig. 10. Procedure of Sequence Replanning (Wiendahl et al., 2008) 
First of all, manufacturing orders have to be selected, which can permute their position in the waiting queue with the rush order without endangering the adherence to their scheduled completion dates. For this purpose, the buffer time $\left(\mathrm{BT}_{\mathrm{i}, \mathrm{Rankmax}}\right)$ of each order has to be calculated according to equation 12 .

$$
B T_{i, \text { Rankmax }}=T_{\text {PlanEndi }}-T_{\text {ref }}-\sum_{k=1}^{n+1} T E X_{k}-T E X_{0, \text { Rest }}
$$

with:

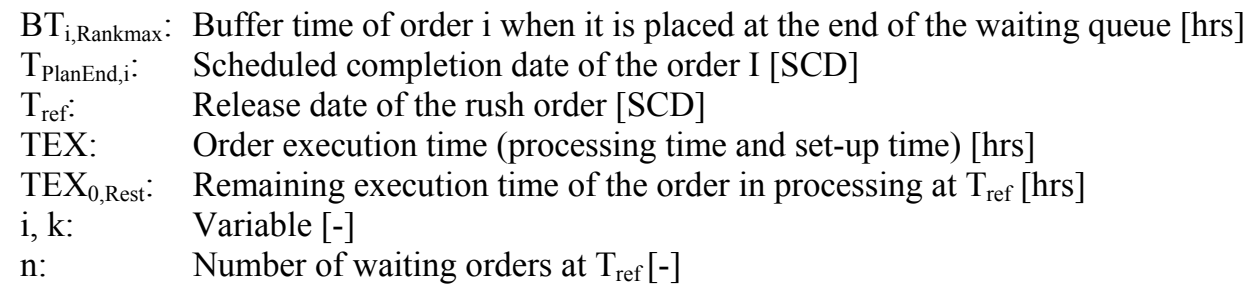

At this level a set $\mathrm{A}$ of selected production orders with a positive buffer time $\mathrm{BT}_{\mathrm{i}, \mathrm{Rankmax}}$ is built (equation 12). Production orders with a negative buffer time can not permute their position with the rush order and consequently are not subject of the following selection levels.

$$
A=\left\{T E X_{i} / i \in[1, n] \forall B T_{i, \text { Rankmax }} \geq 0\right\}
$$

with:

A: $\quad$ Set of production order built at the first selection level [-]

$\mathrm{BT}_{\mathrm{i}, \text { Rankmax }}$ : Buffer time of order $\mathrm{i}$ when it's placed at the end of the waiting queue [hrs]

TEX: $\quad$ Order execution time (processing time and set-up time) [hrs]

i: $\quad$ Variable [-]

$\mathrm{n}$ : Number of waiting orders at $\mathrm{T}_{\mathrm{ref}}[-]$

In order to confirm the first condition for the sequence replanning, production orders have to be selected in the second selection level from the set A. Hereby, only orders may be selected, which permit the completion of the rush order on schedule. Consequently, the set A will be reduced to a new set B of production orders according to the following equation:

$$
B=\left\{T E X_{j} \in A /\left|B T_{R}\right| \leq \sum_{i=j}^{n} T E X_{i}\right\}
$$

with:

B: $\quad$ Set of production order built at the second selection level [-]

A: $\quad$ Set of production order built at the first selection level [-]

$\mathrm{BT}_{\mathrm{R}}$ : $\quad$ Buffer time of order $_{\mathrm{R}}$ (rush order) [hrs]

TEX: Order execution time (processing time and set-up time) [hrs]

$\mathrm{i}, \mathrm{j}: \quad$ Variables [-]

$\mathrm{n}$ : $\quad$ Number of waiting orders at $\mathrm{T}_{\text {ref }}[-]$

The third selection consist in finding out orders from set B, which can permute their position with the rush order without putting the scheduled completion of the remaining orders in the waiting queue at risk. Consequently, both above-cited conditions can be met.

Suppositionally, the $\operatorname{Order}_{j}$ is the order from the set B, which permute its position with the rush order $\left(\operatorname{Order}_{R}\right)$. The difference between the execution time of Order $_{j}$ and $\operatorname{Order}_{R}$ produces a delayed (if negative) or an early completion of remaining production order. Thereby, the delay has to be at most equal to the buffer time of several orders (from $\mathrm{j}+1$ to $\mathrm{n}$ ) so their completion on schedule is ensured. Through the selection of orders, which conform to the cited conditions, a new set $\mathrm{C}$ of orders is built (equation 15). This set contains all orders, whose permutation with the rush order ensures on schedule completion of all order in the production. 


$$
\left\{\begin{array}{l}
C=\left\{T_{E X} \in B / T E X_{R}-T E X_{j} \leq \min \left\{B T_{i} \forall i ; i \in[j+1, n]\right\}\right\} \\
B T=T_{\text {PlanEnd, } i}-T_{\text {ref }}-\sum_{k=1}^{i} T E X_{k}-T E X_{0, R e s t}
\end{array}\right.
$$

with:

C: $\quad$ Set of production order built at the third selection level [-]

B: $\quad$ Set of production order built at the second selection level [-]

BT: $\quad$ Buffer time [hrs]

TEX: $\quad$ Order execution time (processing time and set-up time) [hrs]

$\mathrm{TEX}_{0, \text { Rest }}$ : Remaining execution time of the order in processing at $\mathrm{T}_{\text {ref }}[\mathrm{hrs}]$

$\mathrm{T}_{\text {PlanEnd: }} \quad$ Scheduled completion date [SCD]

$\mathrm{T}_{\text {ref: }} \quad$ Release date of the order ${ }_{n+1}$ [SCD]

$\mathrm{i}, \mathrm{j}, \mathrm{k}$ : $\quad$ Variables [-]

$\mathrm{n}: \quad$ Number of waiting orders at $\mathrm{T}_{\text {ref }}[-]$

In case that the set $\mathrm{C}$ encompasses more than one order the order selection for sequence replanning may take place based on additional criteria e. g. set-up cost or significance of customer. Due to the new sequence the probability of occurrence and the impact of the logistic risk "low schedule reliability" can be reduced. The efficiency of the replanned sequence has to be controlled based on the monitoring and a subsequent risk assessment in the PPC-Controlling (Richter and Potthast 2009) (fig. 1).

\section{Validation}

The validation encompasses the the accuracy of forecasted risk indicators within the risk assessment and the performance of the plan parameter adaption based on the genetic algorithm. For both validations the logistic risk indicator lateness was assessed. Thereby, the lateness is caused by a scheduling failure. The validation was accomplished with material flow simulation based on collected order data from a forging company which produces gearwheels.

Fig. 11 shows a comparison between a value of lateness forecasted with the presented trend analysis (left side of fig. 11) and the value of lateness forecasted using simulation (right side of fig. 11).

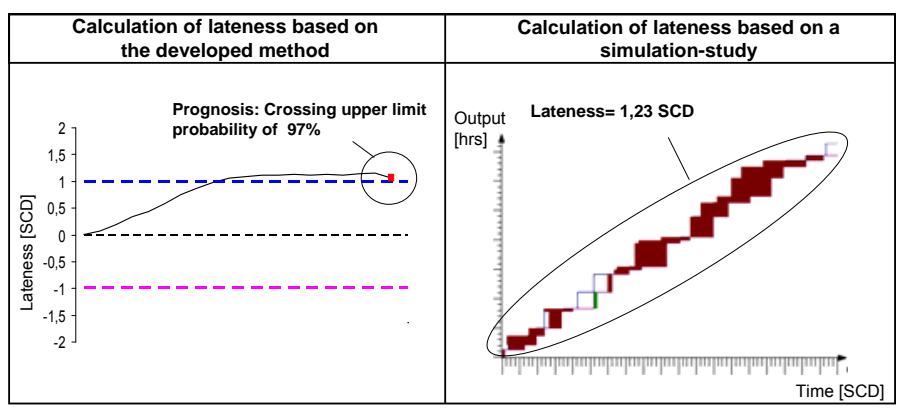

Fig. 11. Comparison of forecasted and simulated lateness

Both forecast values cross the upper limit of the tolerance range $\pm 1 \mathrm{SCD}$. The trend analysis produces a probability of crossing the upper limit amounting 97\%. In accordance, the simulation affirms this probability with a calculated lateness amounting 1.23 SCD. Hence, the proposed method for forecasting risk indicators is suitable.

Within experimental series (30 production orders per simulation) the method for plan parameter adaptation with genetic algorithms was validated. In order to counterbalance the scheduling failure and consequently improve the schedule reliability the genetic algorithms adapted release dates for production orders. Through the defined fitness function positive as well negative deviations are considered (see equation 10). Thereby, the fitness function has to be minimized throughout the optimization. In this example the used mutation probability is amounting to $50 \%$. Furthermore, the mutation degree is established though a distribution form (normal distribution) of the individuals (release dates). The plan parameter adaption ran until a predefined abort criterion (here a max simulation number limited to 500 simulations) was reached.

Fig. 12 shows the optimization result for the even cited example (determining optimized release dates for counterbalancing the logistic risk "low schedule reliability"). The fitness value for each population is charted on the ordinate. The simulations number is given on the $\mathrm{x}$-coordinate. Thereby, the curve progression demonstrates 
a continuous improvement of the schedule reliability (Fitness curve). After 500 simulations a local optimum is reached. Hereby, this optimum accords to a best fitness value amounting 6 days and a mean lateness amounting to 8 hours.

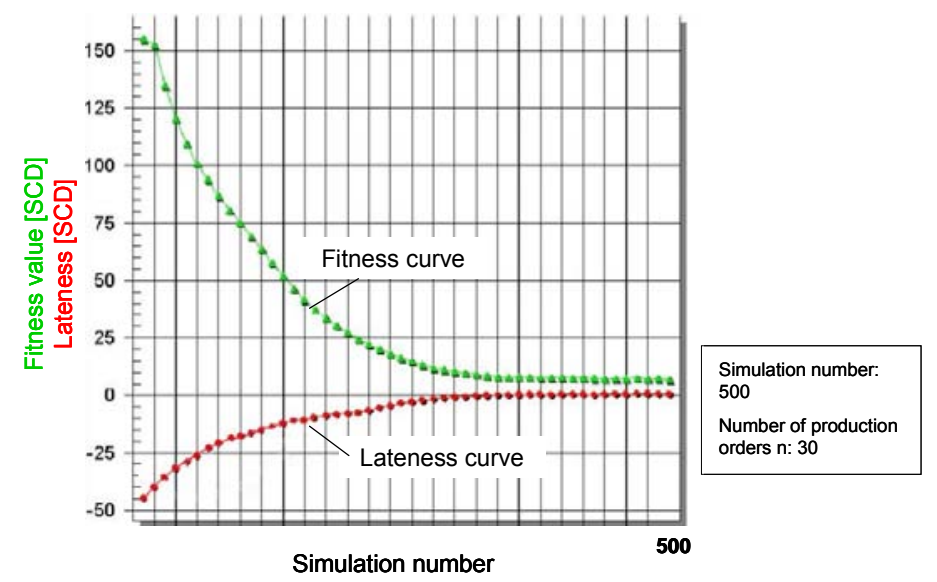

Fig. 12. Genetic Algorithm Optimization of Lateness

The result represents a suitable background for the production planning in order to achieve a high level of schedule reliability. The effect of this plan-parameter adaption has to be continuously controlled based on the logistic monitoring and logistic risk assessment (fig. 1).

\section{Conclusion}

The customers concerning about product cost and product quality on one side as well as fluctuating delivery dates and quantities arrangements on the other side intensify the competitive situation in the forging industries increasingly. The logistic risk management allows coping with the above mentioned turbulences in the logistic environment of forging enterprises through an early identification of potential logistic risks (e. g. demand fluctuation) and an efficient risk control in long term manner (plan-parameter adaption) as well as short term manner (order sequence replanning).

The topic of this paper is to present developed methods for logistic risk management for an exemplary process chain for precision forging. The first step consisted in the identification of logistic risks in the processes source, make and deliver. Then logistic risk indicators (e. g. mean weighted deviation of delivery date) were assigned to the identified logistic risks, in order to ensure a quantitative assessment of logistic risks. In the second step, methods were developed for forecasting the occurence probability of expected values for logistic risk indicators based on the second order exponential smoothing and with consideration of their distribution form. With the expected values of logistic risk indicator a relative economic impact can be determined by using the logisticcosts-effect-model from KERNER. Accordingly, the logistic risks can be ranked. In the third step methods were developed for long term and short term logistic risk control. On the one hand, the described method for planparameter adaption based on genetic algorithms (long term risk control) enables a good planning reliability with a maintainable effort. On the other hand, the presented method for order sequence replanning (short term risk control) aims the positioning of a rush order in an existing waiting queue without disturbing the general schedule reliability in the production. Finally, the presented methods were validated with collected data from forging companies to ensure the practical implementation.

The presented work is performed within the framework of the Collaborative Research Center 489 "Process chain for the manufacturing of precision forged high performance components", in the sub project C4 - "design and control of flexible supply chains for the production of precision forged components". The research project started in the year 2000 and is residing in the 4th funding period until the end of 2011. Fig. 13 shows the project periods and their objectives. 


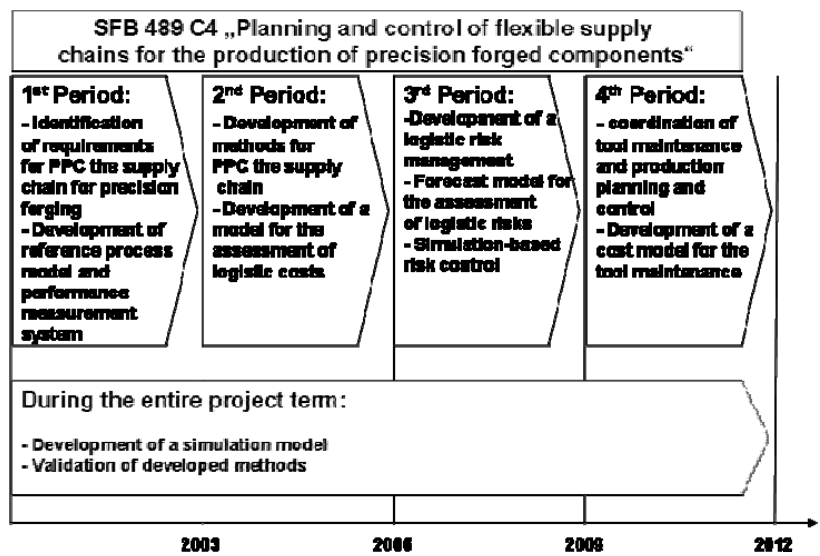

Fig. 13. Research periods of the research project SFB489 C4.

The project is funded by the Deutsche Forschungsgemeinschaft (DFG - German Research Foundation). The authors wish to acknowledge the support.

\section{References}

[Agrawal, V.; Seshardi, S., 2000]

[Alonso-Ayuso, A.; Escudero, L. F.; Garin, A. ;Ortuno, M. T.; Perez, G., 2003]

[Buscher, U.; Wels, A.; Winter, D.-H., 2008]

[Chopra, S.; Sodhi, M. S., 2004]

[Christopher, M., 2005]

[Fang, K.-T., Li, R., Sudjianto, A., 2006]

[Giesbrecht, F., Marcia, F., Gumbertz, L., 2004]

[Goldberg, D.- E., 2002]

[Jacobsen, A.-E., 2006]

[Jüttner, U.; Ziegenbein, A., 2006]

[Kanitz, F., 2002]

[Kerner, A., 2002]
Risk intermediation in supply chains, in: IIE Transactions, 32. Jahrgang, 2000, Heft 9, S. 819-831.

An Approach for Strategic Supply Chain Planning under Uncertainty based on Stochastic 0-1

Programming, in: Journal of Global Optimization, 26. Jahrgang, 2003, Heft 1, S. 97-124.

Eine bibliografische Analyse zum Supply Chain Risikomanagement unter besonderer Berücksichtigung der Risikoquantifizierung. In: Otto, A.; Obermaier, R. (Hrsg.): Logistikmanagement - Analyse, Bewertung und Gestaltung logistischer Systeme. Deutscher Universitäts-Verlag, GWV Fachverlage GmbH, Wiesbaden, 2008.

Managing Risk to avoid supply-chain breakdown, in: MIT Sloan Management Review, 46. Jahrgang, 2004, Heft 1, S. 53-61.

Managing Risk in the Supply Chain, in: Supply Chain Practice, 7.Jahrgang, 2005, Heft 2, S. 4-21.

Design and Modelling for Computer Experiments, Computer science and data analysis serie, Chapman \& Hall/CRC, USA, 2006.

Planning, Construction and Statistical Analysis of Designed Experiments, Wiley \& Sons, New York, USA, 2004.

The Design of Innovation, Lessons from and for Competent Genetic Algorithms, Addison-Wesley, USA, 2002.

Messung und Bewertung von Nachfragedynamik und logistischer Agilität in der Automobilzulieferindustrie. Dissertation, Leibniz University Hannover, 2006.

Risiken in der Supply Chain - Analyse der Risikoprofile in Schweizer Unternehmen. In: Beschaffungsmanagement, Vol 6-7 (2006), S. 12-14.

Kennzahlenbasierte Fehleridentifizierung in der Beschaffungslogistik. Dissertation, Leibniz University of Hanover, Germany, 2002.

Modellbasierte Beurteilung der Logistikkosten von Prozessketten. Dissertation, Leibniz University Hannover, Germany, 2002. 
[Lambert, Douglas M., 2008]

[Lödding, H., 2005]

[Luczak, H.; Eversheim, W.; Schotten, M., 1998]

[Nickel, R., 2008]

[Nyhuis, P.; Wiendahl, H.-P., 2002]

[Ouali, K., Reinsch, S., 2004]

[Reinsch, S., 2003]

[Reinsch, S., 2005]

[Richter, M.; Potthast, J.-M., 2009]

[Sachs, L., 1997]

[Selaouti, A.; Nyhuis, P.; Nickel, R., 2008]

[Simchi-Levi, D.; Kaminsky, P.; Simchi-levi E., 2007]

[Supply-Chain Council, 2009]

[VDI (Association of German Engineers) Gesellschaft Foerdertechnik Materialfluss Logistik, 1997]

[Wiendahl, H.-P.; Selaouti, A.; Nickel, R., 2007]

[Wiendahl, H.-P.; Selaouti, A.; Nickel, R., 2008]

[Wiendahl, H.-P; Selaouti, A.; Nickel, R., 2008]

[Wiendahl, H.-P., 1995]

[Yu, K.-W., 2001]
Supply Chain Management: Processes, Partnerships, Performance. 3rd edition, The Hartley Press, Inc., USA, 2008.

Verfahren der Fertigungssteuerung - Grundlagen, Beschreibung, Konfiguration, Springer-Verlag, Berlin Heidelberg, 2005.

Produktionsplanung und Steuerung, Springer-Verlag, Berlin, Germany, 1998.

Fortsetzungsantrag 2009-2011 Band 2. Sonderforschungsbereich 489 ,Prozesskette zur Herstellung präzisionsgeschmiedeter Hochleistungsbauteile“. Leibniz University Hannover 2008.

Logistische Kennlinien: Grundlagen, Werkzeuge und Anwendungen. 2nd edition, Springer-Verlag, Germany, 2002.

Logistic Performance Controlling - Assessment and Continuous Improvement of Processes, Conference on Competitive Manufacturing, Stellenbosch, South Africa, 2004.

Kennzahlenbasierte Positionierung der Logistik von Lieferketten. Dissertation, Leibniz University of Hanover, Germany, 2003.

Fortsetzungsantrag 2006-2008 Band 2. Sonderforschungsbereich 489 ,Prozesskette zur Herstellung präzisionsgeschmiedeter Hochleistungsbauteile“. Leibniz University Hannover 2005.

Slight PPC Systems Adaption. http://www.logforum.net/pdf/5_1_1_09.pdf, 24.04.2009.

Angewandte Statistik, 8th edition, Springer Verlag, Berlin, Germany, 1997.

Simulation-Based Plan-Parameter Adaptation, Sequence Replanning and Order Splitting for Risk Control within Logistic Risk Management. In: EngOpt 2008 - International Conference on Engineering Optimization Rio de Janeiro, Brazil, 1st - 5th June 2008.

Designing and Managing the Supply Chain. 3rd edition, Mcgraw Hill, USA, 2007.

Supply-Chain Operations Reference-Model - SCOR Overview Version 9.0. http://www.supply-chain.org, 30.07.2009.

Simulation von Logistik-, Materialfluss- und Produktionssystemen. VDI-Guideline 3633, Page 5. Beuth Verlag, Duesseldorf 1997.

Logistic Risk Management for Planning and Control of Flexible Process Chains, ICET 2007:1st International Conference on Engineering Technology, Kuala Lumpur, Malaysia, 11th - 13th December 2007.

Reihenfolgeneuplanung und Auftragsplitting im logistischen Risikomanagement. In: PPS Management, GITO-Verlag, vol. 13 (2008), no. 2, pp. 14-19.

Proactive Supply Chain Management in the Forging Industry. In: WGP - Production Engineering Research and Development, Springer-Verlag, vol. 2 (2008), no. 4, pp. 425-430.

Load-Oriented Manufacturing Control. Springer-Verlag, Germany, 1995.

Terminkennlinie - Eine Beschreibungsmethodik für Terminabweichung im Produktionsbereich,. Dissertation, Leibniz University Hannover, Germany, 2001. 


\section{About the authors}

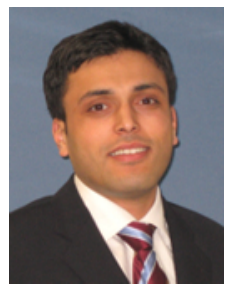

Dipl.-Ing. Anis Selaouti, born in 1980, studied mechanical engineering focussing manufacturing technology and product development at the University of Stuttgart. Since 2007 he is working on his PhD-thesis in the department of logistics at IPH Institute of Integrated Production Hannover (non-profit limited company).

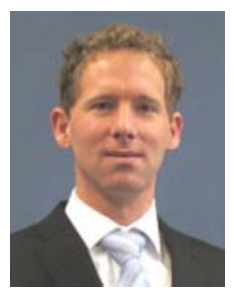

Dipl.-Wirt.-Ing. Dipl.-Ing. (FH) Jens-Michael Potthast, born in 1979, studied economics engineering and mechanical engineering focussing production management, manufacturing technology, product development and performance measurement at the University of Applied Science and Arts in Hannover. In 2005 he started working at the research \& development department at one of the world's leading suppliers to the automotive industry. Since 2008 he is working on his PhD-thesis in the department of logistics at IPH - Institute of Integrated Production Hannover (non-profit limited company).

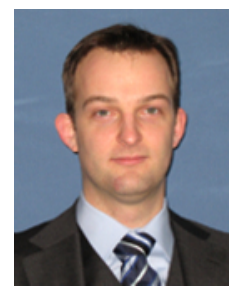

Dr.-Ing. Dipl.-Oec. Rouven Nickel, born in 1975, studied economics focussing production management, manufacturing technology and performance measurement at the Leibniz Universität Hannover. Subsequently, he worked as research associate at the Institute of Production Systems and Logistics (IFA). Since 2007 he is managing director of the IPH - Institute of Integrated Production Hannover (non-profit limited company). In 2008 he received his doctorate in mechanical engineering at the Universität Bremen. 